Article

\title{
Exogenously-Sourced Ethylene Modulates Defense Mechanisms and Promotes Tolerance to Zinc Stress in Mustard (Brassica juncea L.)
}

\author{
M. Iqbal R. Khan ${ }^{1, *}$, Badar Jahan ${ }^{2}$, Mohamed F Alajmi ${ }^{3}$, Md Tabish Rehman ${ }^{3}$ (D) and \\ Nafees A. Khan ${ }^{2}$ \\ 1 Plant Systems Biology Laboratory, Department of Botany, School of Chemical and Life Sciences, \\ Jamia Hamdard, New Delhi 110065, India \\ 2 Plant Physiology and Biochemistry Laboratory, Department of Botany, Aligarh Muslim University, \\ Aligarh 202002, India; naziabadar.2014@gmail.com (B.J.); naf9.amu@gmail.com (N.A.K.) \\ 3 Department of Pharmacognosy, King Saud University, Riyadh 11362, Kingdom of Saudi Arabia; \\ malajmii@ksu.edu.sa (M.F.A.); m.tabish.rehman@gmail.com (M.T.R.) \\ * Correspondence: iqbal.khan@jamiahamdard.ac.in; Tel.: +91-11-26059688-5536
}

Received: 27 October 2019; Accepted: 20 November 2019; Published: 25 November 2019

\begin{abstract}
Heavy metal (HM) contamination of agricultural soil is primarily related to anthropogenic perturbations. Exposure to high concentration of HMs causes toxicity and undesirable effects in plants. In this study, the significance of ethylene was studied in response of mustard (Brassica juncea) to a high level (200 $\mathrm{mg} \mathrm{kg}^{-1}$ soil) of zinc (Zn) exposure. Plants with high Zn showed inhibited photosynthesis and growth with the increase in oxidative stress. Application of ethylene (as ethephon) to Zn-grown plants restored photosynthesis and growth by inhibiting oxidative stress through increased antioxidant activity, the proline metabolism glyoxalase system, and nutrient homoeostasis. The results suggested that ethylene played a role in modulating defense mechanisms for tolerance of plants to Zn stress.
\end{abstract}

Keywords: antioxidant system; ethylene; glyoxalase system; photosynthesis; proline metabolism; zinc

\section{Introduction}

The addition of heavy metals (HMs) to agricultural soil has become a leading problem worldwide due to a wide range of unrestricted and continuous anthropogenic activities, especially in developing countries. In recent times, the increasing concentration of HMs has invited attention in global research due to their non-biodegradability and their high accumulation in living things through the food web [1]. Heavy metals that serve as micronutrients, such as copper $(\mathrm{Cu})$, iron $(\mathrm{Fe})$, manganese $(\mathrm{Mn})$, cobalt (Co), nickel (Ni), and zinc (Zn) play an essential function in plant growth and development under optimal concentrations [2,3]. Zinc, included in this category, has essential roles in binding of protein, regulation of enzyme activity, transcriptional and translational regulation, and signal transduction in being a component and co-factor of several enzymes [4,5]. The deficiency of $\mathrm{Zn}$ results in necrotic spots, leaf chlorosis, nutrient imbalance, altered cell division, and reduced photosynthesis and growth [6,7]. The presence of 8.0-100 $\mathrm{g} \mathrm{g} \mathrm{g}^{-1} \mathrm{DW} \mathrm{Zn}$ has been suggested to assist normal growth and development of plants, but at elevated concentrations of $300 \mu \mathrm{g} \mathrm{g}^{-1}$ it becomes a toxic pollutant [8,9] and causes overproduction of reactive oxygen species (ROS) $[10,11]$. Under these conditions, it significantly induces cellular damages, redox imbalance, replacement of essential functional groups, and inhibition of photosynthetic and growth processes [12].

Plants have inherent capabilities to strive under such stressful environments by way of modifying diverse defense mechanisms to scavenge/regulate the excess ROS in plants. The antioxidant 
enzymes, such as superoxide dismutase (SOD), ascorbate peroxidase (APX), glutathione peroxidase (GPX), glutathione S-transferase (GST), glutathione reductase (GR), monodehydroascorbate reductase (MDHAR), and dehydroascorbate reductase (DHAR), are activated for survival $[13,14]$. The co-substrates of ascorbate-glutathione (AsA-GSH) cycle, GSH and AsA, serve as non-enzymatic antioxidants for direct scavenging of ROS [15]. Under stress condition, increased production of a highly reactive substance, $\alpha$-ketoaldehydes called methylglyoxals (MG), can damage cellular ultrastructure, causing inactivation of proteins and even cell death [16]. Consequently, efficient MG detoxification has become a necessary biochemical indicator for stress tolerance, where reduced glutathione (GSH)-dependent glyoxalase pathway efficiently performs MG detoxification via glyoxalase I (Gly I) and glyoxalase II (Gly II) enzymes [16]. Another potential mechanism for tolerance of plants to HM stress is proline accumulation [17]. Proline potentiality detoxifies excess ROS, maintains cellular osmotic environment, protects biological membranes, and stabilizes enzymes/proteins under stress conditions [18]. Thus, proline metabolism may also be considered as a strategy to increase tolerance of plants to HMs and to protect photosynthesis.

Ethylene is a simple gaseous plant hormone that interacts with nutrient uptake and potentially influences many developmental processes of plants, including photosynthesis, under optimal and stressful conditions [19,20]. Iqbal et al. [21] showed that supplementation of ethephon resulted in increased activity of nitrate reductase and ATP-sulfurylase, which accounted for enhanced assimilation of nitrogen $(\mathrm{N})$ and sulfur $(\mathrm{S})$ resulting in increased antioxidant activity and photosynthetic responses in mustard plants. In wheat plants under heat stress [22] and cadmium (Cd) stress [23], ethylene regulates proline production. In spite of the fact that ethylene has now been recognized as an important modulator of photosynthetic process under optimal and stressful environments, its involvement in regulation of plant tolerance to elevated $\mathrm{Zn}$ levels through coordination of antioxidant and glyoxalase enzyme systems and proline metabolism has not been clearly demonstrated. It is postulated that the measures that could increase $\mathrm{N}$-use efficiency in plants may result in greater investment of $\mathrm{N}$ in cellular metabolites and induce mechanisms that could protect photosynthesis and plant dry mass, and confer tolerance to $\mathrm{Zn}$ stress, through involvement of enhanced activity of antioxidant and glyoxalase systems and proline biosynthesis. The exogenously applied ethylene could help in achieving these processes and in alleviation of the adverse effects of $\mathrm{Zn}$-induced stress.

\section{Material and Methods}

\subsection{Plant Material, Growth Conditions, and Treatments}

Healthy seeds of mustard (Brassica juncea L. Czern \& Coss. cv. Varuna) were sterilized using $0.01 \mathrm{~g} \mathrm{~L}^{-1}$ mercuric chloride solution and repeated washings with double distilled water. The seeds were sown in earthen pots filled with soil having peat and compost, 4:1 $(v / v)$, and mixed with sand, 3:1 $(v / v)$. In each pot, five healthy plants were maintained after seedling establishment. The experiments were conducted at the Department of Botany, Aligarh Muslim University, Aligarh, India in the naturally illuminated green house. The plants grown with $200 \mathrm{mg} \mathrm{Zn} \mathrm{kg}^{-1}$ soil (considered on the basis of our earlier research) [24] were treated with $200 \mu \mathrm{L} \mathrm{L}^{-1}$ ethephon at 20 days after sowing (DAS). The source for $\mathrm{Zn}$ was $\mathrm{ZnSO}_{4}$. In addition, a control group of plants and plants treated with $200 \mu \mathrm{L} \mathrm{L}^{-1}$ ethephon alone were also maintained. The application of $200 \mu \mathrm{L} \mathrm{L}^{-1}$ ethephon was done with a hand sprayer along with $0.5 \%$ teepol as surfactant. To maintain the effects of ethephon releasing ethylene, a high soil phosphorus (P) status was maintained as described earlier as Khan and Khan [24]. The treatments were arranged in a completely randomized block design and five replicates for each treatment were maintained $(n=3)$. All measurements were done at 30 DAS to record different physiological, biochemical, and growth attributes. 


\subsection{Measurements of Photosynthetic Traits and Plant Dry Mass Accumulation}

Gas exchange parameters (stomatal conductance (gs), intercellular $\mathrm{CO}_{2}$ concentration $(\mathrm{Ci})$, and net photosynthesis (Pn) were measured in the fully expanded uppermost leaves of plants in each treatment using infrared gas analyzer (CID-340, Photosynthesis System, Bio-Science, Washington, USA). The measurements were done between 11:00 and 12:00 at light saturating intensity and at $370 \pm 5 \mu \mathrm{mol} \mathrm{mol}^{-1}$ atmospheric $\mathrm{CO}_{2}$ concentration.

Chlorophyll content was measured with the help of a SPAD chlorophyll meter (SPAD 502 DL PLUS, Spectrum Technologies, Aurora, IL, USA).

Activity of ribulose-1,5-bisphosphate carboxylase (Rubisco) (EC 4.1.1.39) was determined spectrophotometrically by the adopting the method of Usuda [25] by monitoring nicotinamide adenine dinucleotide (NADH) oxidation at $30{ }^{\circ} \mathrm{C}$ at $340 \mathrm{~nm}$ during the conversion of 3-phosphoglycerate to glycerol 3-phosphate after the addition of enzyme extract to the assay medium. Further detail is given by Khan and Khan [24].

By using a Junior-PAM chlorophyll fluorometer (Heinz Walz, Effeltrich, Germany) all the chlorophyll fluorescence parameters were studied as described earlier by Khan and Khan [24]. Calculations were done according to Khan and Khan [24] and Krall and Edwards [26].

Dry mass of plants was recorded after drying the sample in a hot air oven at $80^{\circ} \mathrm{C}$ till constant weight. Leaf area was measured using a leaf area meter (LA211, Systronics, New Delhi, India).

\subsection{Determination of Oxidative Stress Markers}

\subsubsection{Lipid Peroxidation}

Lipid peroxidation in leaves was determined by estimating the content of thiobarbituric acid reactive substances (TBARS) as described by Dhindsa et al. [27]. The content of TBARS was calculated using the extinction coefficient $\left(155 \mathrm{mM}^{-1} \mathrm{~cm}^{-1}\right)$. The details have been given in our earlier report as Khan et al. [22].

\subsubsection{Electrolyte leakage}

For measuring electrolyte leakage, samples were thoroughly washed with sterile water, weighed, and then kept in closed vials with $10 \mathrm{~mL}$ of deionized water where they were incubated at $25^{\circ} \mathrm{C}$ for $6 \mathrm{~h}$ using a shaker. Then, electrical conductivity (EC) was determined (C1). Samples were then again kept at $90^{\circ} \mathrm{C}$ for $2 \mathrm{~h}$ and EC was recorded after attaining equilibrium at $25^{\circ} \mathrm{C}(\mathrm{C} 2)$.

\subsubsection{Methylglyoxal Content}

Adopting the method of Wild et al. [28], methylglyoxal content was measured. Leaf samples were homogenized by using $5 \%$ perchloric acid followed by centrifugation at $11,000 \times g$. A saturated solution of $\mathrm{Na}_{2} \mathrm{CO}_{3}$ was used to neutralize the supernatant and further mixed with $\mathrm{Na}-\mathrm{P}$ and $\mathrm{N}$-acetyl-L-cysteine. The product $\mathrm{N}$ - $\alpha$-acetyl-S-(1-hydroxy-2-oxoprop-1-yl) cysteine formation was measured by spectrophotometer at $288 \mathrm{~nm}$. A standard curve of MG was prepared and expressed in $\mu \mathrm{mol} \mathrm{g}^{-1} \mathrm{FW}$.

\subsubsection{Lipoxygenase Activity}

Lipoxygenase (LOX) (EC 1.13.11.12) activity was estimated following the method of Doderer et al. [29] by monitoring the increase in absorbance at $234 \mathrm{~nm}$ using linoleic acid as a substrate. The LOX activity was calculated using $25 \mathrm{mM}^{-1} \mathrm{~cm}^{-1}$ as an extinction coefficient.

\subsection{Measurement of Ascorbate and Glutathione Content}

\subsubsection{Ascorbate Content}

Ascorbate (AsA) content was determined following the method of Law et al. [30] with some modifications. The details have been given in our earlier report as Anjum et al. [31]. A standard 
curve in the range of 10-100 nmol of ascorbic acid was used for calibration. Values in both cases were corrected for the absorbance eliminating the supernatant in the blank prepared separately for AsA.

\subsubsection{Reduced Glutathione Content}

GSH was assayed by an enzymic recycling procedure, as detailed by Griffith [32], in which it was sequentially oxidized by 5,5-dithiobis-2-nitrobenzoic acid (DTNB) and reduced by NADPH in the presence of GR, as described earlier [24,33].

\subsection{Extraction and Determination of Antioxidant Enzymes}

Fresh leaf tissue (200 mg) was homogenized with an extraction buffer containing $0.05 \%(v / v)$ Triton X-100 and 1\% (w/v) PVP in potassium-phosphate buffer (100 mM, pH 7.0) using chilled mortar and pestle. At $4{ }^{\circ} \mathrm{C}$, the homogenate was centrifuged at $15,000 \times g$ for $20 \mathrm{~min}$. The supernatant obtained after centrifugation was used to assay superoxide dismutase (SOD) (EC 1.15.1.1), GSH reductase (GR) (EC 1.6.4.2), and GSH peroxidase (GPX) (EC 1.11.1.9) enzymes, and for the assay of ascorbate peroxidase (APX) (EC 1.11.1.11). Here, $2.0 \mathrm{mM}$ ascorbate was supplemented with extraction buffer. Protein was estimated according to Bradford [34] using bovine serum albumin as standard.

\subsubsection{SOD}

Activity of SOD was determined by monitoring the inhibition of photochemical reduction of nitro blue tetrazolium (NBT), according to the methods of Beyer and Fridovich [35] and Giannopolitis and Ries [36]. The details have been given in our earlier report as Khan and Khan [24].

\subsubsection{APX}

Activity of APX was determined by the method of Nakano and Asada [37] by recording the decrease in absorbance of ascorbate at $290 \mathrm{~nm}$. The assay mixture contained phosphate buffer $(50 \mathrm{mM}$, $\mathrm{pH} 7.0$ ), $0.1 \mathrm{mM}$ EDTA, $0.5 \mathrm{mM}$ ascorbate, $0.1 \mathrm{mM} \mathrm{H}_{2} \mathrm{O}_{2}$, and the enzyme extract. APX activity was calculated by using the extinction coefficient $2.8 \mathrm{mM}^{-1} \mathrm{~cm}^{-1}$. One unit of the enzyme is the amount necessary to decompose $1 \mu \mathrm{mol}$ of substrate per min at $25^{\circ} \mathrm{C}$.

\subsubsection{GR}

Activity of GR was determined adopting the method of Foyer and Halliwell [38] by monitoring the GSH-dependent oxidation of NADPH. The details have been given in our earlier report as Khan and Khan [24].

\subsubsection{GPX}

Activity of GPX was determined by adopting the method of Hasanuzzaman et al. [39]. The details have been given in our earlier report as Khan et al. [24].

\subsubsection{GST}

Glutathione S-transferase (GST) (EC 2.5.1.18) was determined spectrophotometrically by the method Booth et al. [40] with some modifications [41]. The reaction mixture contained $100 \mathrm{mM}$ Tris- $\mathrm{HCl}$ buffer ( $\mathrm{pH}$ 6.5), $1.5 \mathrm{mM} \mathrm{GSH}, 1 \mathrm{mM}$ 1-chloro-2,4-dinitrobenzene (CDNB), and enzyme solution in a final volume of $0.7 \mathrm{~mL}$. The enzyme reaction was initiated by the addition of CDNB and the increase in absorbance was measured at $340 \mathrm{~nm}$ for $1 \mathrm{~min}$. The activity was calculated using the extinction coefficient of $9.6 \mathrm{mM}^{-1} \mathrm{~cm}^{-1}$.

\subsubsection{MDHAR}

Monodehydroascorbate reductase (MDHAR) (EC 1.6.5.4) activity was assayed by the method of Hossain et al. [42]. The reaction mixture contained $50 \mathrm{mM}$ Tris- $\mathrm{HCl}$ buffer ( $\mathrm{pH} 7.5), 0.2 \mathrm{mM} \mathrm{NADPH}$, 
$2.5 \mathrm{mMAsA}$, and 0.5 units of $\mathrm{AO}$ and enzyme solution in a final volume of $0.7 \mathrm{~mL}$. The reaction was started by the addition of AO. The activity was calculated from the change in ascorbate at $340 \mathrm{~nm}$ for $1 \mathrm{~min}$ using an extinction coefficient of $6.2 \mathrm{mM}^{-1} \mathrm{~cm}^{-1}$.

\subsubsection{DHAR}

Dehydroascorbate reductase (DHAR) (EC 1.8.5.1) activity was assayed by the method of Nakano and Asada [37]. The reaction buffer contained $50 \mathrm{mM} \mathrm{K-phosphate} \mathrm{buffer} \mathrm{(pH} \mathrm{7.0),} 2.5 \mathrm{mM} \mathrm{GSH}$, and $0.1 \mathrm{mM}$ DHA. The reaction was started by adding the sample solution to the reaction buffer solution. The activity was calculated from the change in absorbance at $265 \mathrm{~nm}$ for $1 \mathrm{~min}$ using an extinction coefficient of $14 \mathrm{mM}^{-1} \mathrm{~cm}^{-1}$.

\subsection{Extraction and Assay of Glyoxalase Systems' Enzymes}

\subsubsection{Gly I Activity}

Glyoxalase I (Gly I) (EC 4.4.1.5) assay was determined by the method of Hasanuzzaman et al. [43]. The assay mixture contained $100 \mathrm{mM} \mathrm{K-phosphate} \mathrm{buffer} \mathrm{(pH} \mathrm{7.0),} 15 \mathrm{mM} \mathrm{MgSO}_{4}, 1.7 \mathrm{mM} \mathrm{GSH}$, and $3.5 \mathrm{mM} \mathrm{MG}$ in a final volume of $700 \mu \mathrm{L}$. The reaction was started by the addition of MG and the increase in absorbance was recorded at $240 \mathrm{~nm}$ for $1 \mathrm{~min}$. The activity was calculated using the extinction coefficient of $3.37 \mathrm{mM}^{-1} \mathrm{~cm}^{-1}$.

\subsubsection{Gly II Activity}

Glyoxalase II (Gly II) (EC 3.1.2.6) activity was measured using the method of Principato et al. [44] by monitoring the formation of GSH at $412 \mathrm{~nm}$ for $1 \mathrm{~min}$. The reaction mixture contained $100 \mathrm{Mm}$ Tris- $\mathrm{HCl}$ buffers ( $\mathrm{pH}$ 7.2), $0.2 \mathrm{mM}$ DTNB and $1 \mathrm{mM} \mathrm{S-D-lactoylglutathione} \mathrm{(SLG)} \mathrm{in} \mathrm{a} \mathrm{final} \mathrm{volume}$ of $1 \mathrm{~mL}$. The reaction was started by the addition of SLG and the activity was calculated using the extinction coefficient of $13.6 \mathrm{mM}^{-1} \mathrm{~cm}^{-1}$.

\subsection{Determination of Nutrient Content}

The determination of mineral nutrients (nitrogen, N; phosphorous, P; potassium, $\mathrm{K}$; and calcium, $\mathrm{Ca}$ ) was done in acid-peroxide digested oven-dried leaf sample. $\mathrm{K}$, and $\mathrm{Ca}$ were measured using flame photometer (Khera-391: Khera Instruments, New Delhi, India), whereas N and P were determined by using the methods of Lindner [45] and Fiske and Subba Row [46], respectively.

\subsection{Determination of Proline Content and Activity of Proline Metabolizing Enzymes}

\subsubsection{Proline Content}

Proline content was determined by adopting the ninhydrin method of Bates et al. [47]. Here, $300 \mathrm{mg}$ fresh leaf samples were homogenized in 3\% sulphosalicylic acid $(3 \mathrm{~mL})$. After this, samples were homogenate filtrated and reacted with acid ninhydrin and glacial acetic acid (1 mL each) for $1 \mathrm{~h}$ followed by water bath at $100{ }^{\circ} \mathrm{C}$. The reaction mixture was extracted with toluene and the absorbance was measured at $520 \mathrm{~nm}$. A standard was also prepared using L-proline.

To determine the activity of $\gamma$-glutamyl kinase (GK) (EC 2.7.2.11) and proline oxidase (PROX) (EC 1.5.99.8), enzyme extract was prepared by homogenizing $500 \mathrm{mg}$ leaf sample in $0.1 \mathrm{M}$ Tris- $\mathrm{HCl}$ buffer (pH 7.5) at $4{ }^{\circ} \mathrm{C}$. The homogenate was centrifuged at $30,000 \times g$ for $30 \mathrm{~min}$ and the supernatant was used as the crude extract enzyme preparation for P5CS activity while the pellet was collected and used as extract for the assay of GK and proline oxidase.

\subsubsection{GK Activity}

Activity of GK was assayed by the method of Hayzer and Leisinger [48] with slight modification. The frozen sample was suspended in $10 \mathrm{~mL}$ of $0.1 \mathrm{M}$ Tris- $\mathrm{HCl}$ buffer containing $1 \mathrm{mM}$ 1,4-dithiothreitol 
(DTT) to rupture the cell and centrifuged at $30,000 \times g$ for $30 \mathrm{~min}$. The other detail has been given in our earlier report as Khan et al. [22]. Activity of GK was expressed in $\mathrm{U} \mathrm{mg}^{-1}$ protein. One unit of the enzyme activity is defined as $\mu \mathrm{g}$ of glutamyl hydroxamate $\mathrm{min}^{-1} \mathrm{mg}^{-1}$ protein. Glutamyl hydroxamate was used as standard.

\subsubsection{POX Activity}

Activity of POX was determined adopting the method of Huang and Cavalieri [49] with slight modification. The pellet was mixed with $1 \mathrm{~mL}$ Tricine and $\mathrm{KOH}$ buffer $(\mathrm{pH} 7.5)$ containing $6 \mathrm{M}$ sucrose. This extract was used for the enzyme assay. The other detail has been given in our earlier report as Khan et al. [22]. Proline oxidase activity was expressed in $\mathrm{U} \mathrm{mg}^{-1}$ protein. One unit of the enzyme activity is defined as $\mathrm{mM}$ DCPIP reduced $\mathrm{min}^{-1} \mathrm{mg}^{-1}$ protein.

\subsection{Water Potential and Osmotic Potential}

Leaf water potential was measured on the second leaf from the top (fully expanded young leaf) of the plant by using the water potential system (Psypro, WESCOR, UT, USA). The leaf used for water potential measurement was frozen in liquid $\mathrm{N}_{2}$ in sealed polythene bags which were thawed, and cell sap was extracted with the help of a disposable syringe. The extracted sap was used for the determination of osmotic potential using a vapor pressure osmometer (5520, WESCOR, UT, USA).

\subsection{Statistical Analysis}

Data were analyzed statistically, and standard error was calculated. Analysis of variance was performed on the data using SPSS (ver. 17.0 Inc.) to determine the significance at $p<0.05$. Least significant difference (LSD) was calculated for the significant data to identify difference in the mean of the treatment; data are presented as mean $\pm \operatorname{SE}(n=3)$.

\section{Results}

\subsection{Ethephon Reverses Effects of Zn Stress on Photosynthetic and Growth Attributes}

Photosynthetic attributes were reduced in plants treated with $\mathrm{Zn}$ compared to the control plants. The adverse effect of $\mathrm{Zn}$ stress on photosynthetic parameters was reversed with ethephon application. Ethephon application to plants without $\mathrm{Zn}$ treatment enhanced net photosynthesis by $27.2 \%$, stomatal conductance by $20.5 \%$, intracellular $\mathrm{CO}_{2}$ concentration by $17.2 \%$, Rubisco content by $28.8 \%$, and chlorophyll content by $25.7 \%$, as compared to the control plants. In plants treated with $\mathrm{Zn}$, ethephon supplementation restricted the adverse effects of $\mathrm{Zn}$ and the decrease in net photosynthesis was reduced to $18.1 \%$, stomatal conductance to $13.1 \%$, intracellular $\mathrm{CO}_{2}$ concentration to $15.4 \%$, Rubisco content to $16.4 \%$, and chlorophyll content to $16 \%$, in comparison to control (Table 1).

Plants grown with Zn stress exhibited a decrease in maximum PSII efficiency, intrinsic PSII efficiency, actual PSII efficiency, photochemical quenching, and electron transport rate by $26 \%, 23 \%$, $29 \%, 24 \%$, and $25 \%$ in comparison with the control plants. However, non-photochemical quenching increased with $\mathrm{Zn}$ by $59.2 \%$ as compared to the control. Ethephon application to plants without $\mathrm{Zn}$ stress improved all the above traits compared with control (Table 1).

Growth of plants was reduced with Zn when compared to the control plants. Ethephon application to plants without $\mathrm{Zn}$ treatment enhanced plant dry mass and leaf area compared to the control plants. In plants treated with $\mathrm{Zn}$, ethephon supplementation restricted the adverse effects of $\mathrm{Zn}$ and the decrease in plant dry mass was limited to $15 \%$ as compared to control plants. $\mathrm{Zn}$ reduced leaf area by $30.3 \%$ compared to control (Table 1). Ethephon application to plants without $\mathrm{Zn}$ treatment enhanced plant dry mass and leaf area compared to the control plants. The increases in plant dry mass and leaf area were $23 \%$ and $27 \%$, respectively, compared to the control (Table 1 ). 
Table 1. Chlorophyll content, net photosynthesis rate, intracellular $\mathrm{CO}_{2}$ concentration, stomatal conductance, Rubisco activity, $\Phi$ PS II, Fv/Fm, Fv'/Fm', qP, NPQ, ETR, plant dry mass, and leaf area in the leaf of mustard (Brassica juncea L.) cv. Varuna at 30 days after sowing (DAS). Plants were grown with/without zinc stress and treated with $200 \mu \mathrm{L} \mathrm{L}^{-1}$ ethephon at 20 DAS. Data are presented as treatment mean \pm SE $(n=3)$. Data followed by same letter are not significantly different by least significant difference (LSD) test at $p<0.05$.

\begin{tabular}{|c|c|c|c|c|}
\hline & Control & Ethephon & Zinc & Ethephon + Zinc \\
\hline Chlorophyll content (SPAD value) & $31.4 \pm 1.3^{\mathrm{b}}$ & $39.5 \pm 1.6^{\mathrm{a}}$ & $21.3 \pm 0.8^{\mathrm{d}}$ & $26.4 \pm 0.9^{c}$ \\
\hline Net photosynthesis $\left(\mu \mathrm{mol} \mathrm{CO} \mathrm{Cm}^{-2} \mathrm{~s}^{-1}\right)$ & $19.8 \pm 0.8^{\mathrm{b}}$ & $25.2 \pm 0.9^{a}$ & $11.2 \pm 0.7^{\mathrm{d}}$ & $16.2 \pm 0.6^{c}$ \\
\hline Intracellular $\mathrm{CO}_{2}$ concentration $\left(\mu \mathrm{mol} \mathrm{CO} \mathrm{Col}^{-1}\right)$ & $272 \pm 10.9^{b}$ & $319 \pm 12.7^{\mathrm{a}}$ & $187 \pm 6.7^{\mathrm{d}}$ & $230 \pm 8.2^{c}$ \\
\hline Stomatal conductance $\left(\mathrm{mmol} \mathrm{CO} 2 \mathrm{~m}^{-2} \mathrm{~s}^{-1}\right)$ & $380 \pm 10.7^{b}$ & $458 \pm 12.3^{\text {a }}$ & $280 \pm 10.1^{\mathrm{d}}$ & $330 \pm 11.8^{\mathrm{c}}$ \\
\hline Rubisco activity $\left(\mu \mathrm{mol} \mathrm{CO} \mathrm{Cm}^{-2} \mathrm{~s}^{-1}\right)$ & $48.6 \pm 1.9^{b}$ & $62.6 \pm 2.2^{\mathrm{a}}$ & $32.5 \pm 1.17^{\mathrm{d}}$ & $40.6 \pm 1.5^{c}$ \\
\hline Actual PSII efficiency ( $\Phi$ PS II) & $0.62 \pm 0.03^{a b}$ & $0.68 \pm 0.04^{\mathrm{a}}$ & $0.44 \pm 0.02^{c}$ & $0.57 \pm 0.02^{b}$ \\
\hline Maximum PSII efficiency (Fv/Fm) & $0.77 \pm 0.03^{\mathrm{a}}$ & $0.84 \pm 0.03^{\mathrm{a}}$ & $0.57 \pm 0.02^{c}$ & $0.67 \pm 0.03^{b}$ \\
\hline Intrinsic PSII efficiency $\left(\mathrm{Fv}^{\prime} / \mathrm{Fm}^{\prime}\right)$ & $0.71 \pm 0.03^{b}$ & $0.75 \pm 0.03^{a}$ & $0.55 \pm 0.02^{c}$ & $0.65 \pm 0.02^{b}$ \\
\hline Photochemical quenching ( $\mathrm{qP}$ ) & $0.83 \pm 0.04^{\mathrm{a}}$ & $0.87 \pm 0.03^{\mathrm{a}}$ & $0.63 \pm 0.02^{c}$ & $0.73 \pm 0.03^{b}$ \\
\hline Non-photochemical quenching (NPQ) & $0.54 \pm 0.02 \mathrm{bc}$ & $0.49 \pm 0.03^{c}$ & $0.86 \pm 0.03^{\mathrm{a}}$ & $0.62 \pm 0.03^{b}$ \\
\hline Electron transport rate (ETR) & $154 \pm 6.2^{\mathrm{a}}$ & $167 \pm 5.1^{\mathrm{a}}$ & $116 \pm 4.2^{\mathrm{c}}$ & $135 \pm 5.3^{b}$ \\
\hline Plant dry mass (g plant $\left.{ }^{-1}\right)$ & $6.11 \pm 0.6^{\mathrm{ab}}$ & $7.54 \pm 0.4^{\mathrm{a}}$ & $3.58 \pm 0.4^{c}$ & $5.2 \pm 0.5^{b}$ \\
\hline Leaf area $\left(\mathrm{cm}^{2}\right.$ plant $\left.^{-1}\right)$ & $140 \pm 5.7^{b}$ & $178 \pm 6.1^{\mathrm{a}}$ & $97.5 \pm 3.8^{\mathrm{d}}$ & $121 \pm 4.6^{c}$ \\
\hline
\end{tabular}

\subsection{Influence of Ethephon on Water Relations under Zn Stress}

Application of ethephon to Zn-stressed plants increased water potential by 35\% and osmotic potential by $47 \%$ as compared to the control plants. On the other hand, application of $\mathrm{Zn}$ alone resulted in the increase of water potential by $141 \%$ and osmotic potential by $71.4 \%$ as compared to the control plants (Figure 1).

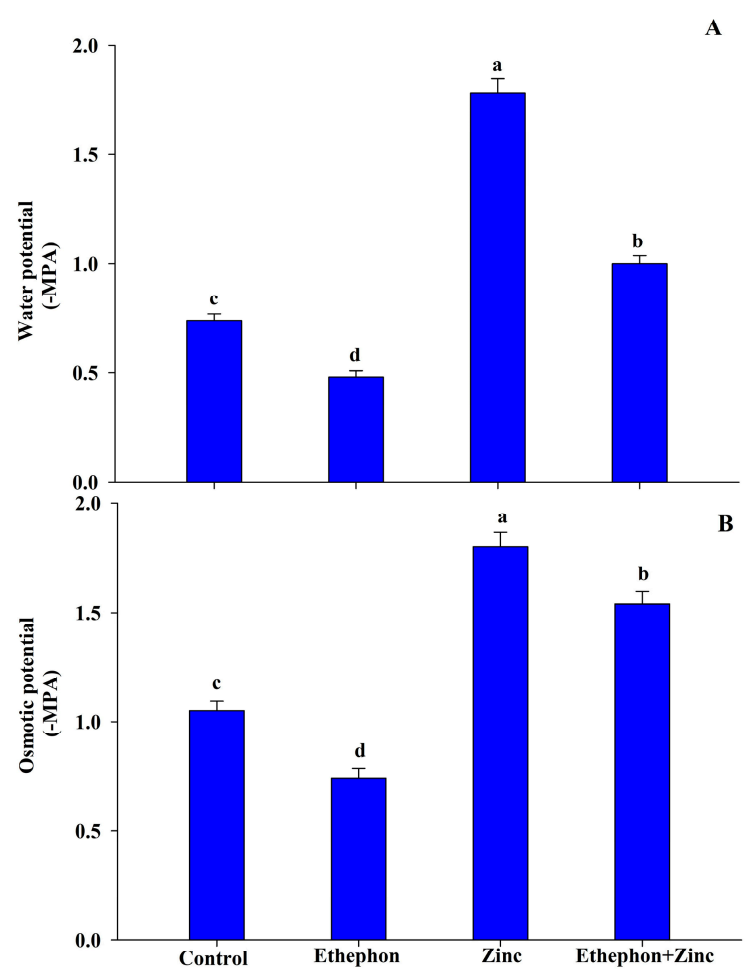

Figure 1. (A) Leaf water potential and (B) osmotic potential in the leaf of mustard (Brassica juncea L.) of Varuna cultivar at 30 DAS. Plants were grown with/without $\mathrm{Zn}$ stress and treated with $200 \mu \mathrm{L} \mathrm{L}^{-1}$ ethephon at 20 DAS. Data are presented as treatment mean \pm SE $(n=3)$. Data followed by same letter are not significantly different by LSD test at $p<0.05$. 


\subsection{Ethephon Reduces Zn-Induced Oxidative Stress}

Plants grown with $\mathrm{Zn}$ showed higher oxidative stress and exhibited increased oxidative stress markers, i.e., content of TBARS and electrolyte leakage, MG content, and LOX activity (Table 2). Treatment of plants with Zn enhanced TBARS content, MG content, and LOX activity by about $95 \%, 61 \%$ and $51 \%$, respectively, whereas electrolyte leakage increased by about 2.2 times in plants compared to the control. For the appraisal of the influence of ethylene in reducing Zn-induced oxidative stress, we analyzed TBARS content and electrolyte leakage after application of ethylene to these plants. Application of ethylene proved effective in lowering oxidative stress under the metal stress. Application of ethylene reduced TBARS content, MG content, and LOX activity by $28 \%, 13 \%$ and $12 \%$, respectively whereas electrolyte leakage was reduced by $47 \%$ in $\mathrm{Zn}$-treated plants compared to Zn-treated plants (Table 2).

Table 2. Electrolyte leakage, thiobarbituric acid reactive substances (TBARS) content, methylglyoxal (MG) content, lipoxygenase (LOX) activity in the leaf of mustard (Brassica juncea L.) cv. Varuna at 30 DAS. Plants were grown with/without zinc stress and treated with $200 \mu \mathrm{L} \mathrm{L}^{-1}$ ethephon at 20 DAS. Data are presented as treatment mean $\pm \mathrm{SE}(n=3)$. Data followed by same letter are not significantly different by LSD test at $p<0.05$.

\begin{tabular}{|c|c|c|c|c|}
\hline & Control & Ethephon & Zinc & Ethephon + Zinc \\
\hline TBARS content (nmol g $\left.{ }^{-1} \mathrm{FW}\right)$ & $13.24 \pm 0.6^{\mathrm{c}}$ & $8.23 \pm 0.4^{\mathrm{d}}$ & $25.84 \pm 0.8^{a}$ & $18.56 \pm 0.7^{b}$ \\
\hline Lipoxygenase activity ( $\mu \mathrm{mol} \mathrm{min}^{-1} \mathrm{mg}^{-1}$ protein) & $10.2 \pm 0.6^{c}$ & $7.9 \pm 0.6^{\mathrm{d}}$ & $15.4 \pm 0.6^{\mathrm{a}}$ & $13.5 \pm 0.6^{b}$ \\
\hline
\end{tabular}

\subsection{Application of Ethephon Enhanced Antioxidant Systems under Zn Stress}

The activities of enzymatic and non-enzymatic antioxidant systems showed modulation with ethylene treatment in both stress and non-stress conditions. Zn stress decreased AsA content as compared to the control plants. On the other hand, ethephon supplementation of Zn-exposed plants had significantly higher AsA content as compared to Zn-treated plants. Under Zn stress, GSH content was increased by $22 \%$ as compared to control plants. Application of ethephon to Zn-exposed plants had significantly higher GSH content by $65 \%$ as compared to the control plants (Figure 2).

Zinc treatment resulted in increased activity of SOD, APX, GR, and GPX by $25 \%, 38 \%, 45 \%$, and $35 \%$, respectively compared to the control plants. In non-stressed control plants, application of ethephon increased activity of SOD APX, GR, and GPX by 50\%, 128\%, 105\%, and 124\%, respectively, over the control. However, application of ethephon to $\mathrm{Zn}$-treated plants resulted in increased activity of SOD, APX, GR, and GPX by $71 \%, 176 \%, 145 \%$, and $165 \%$, respectively, compared to the control (Figure 3). 


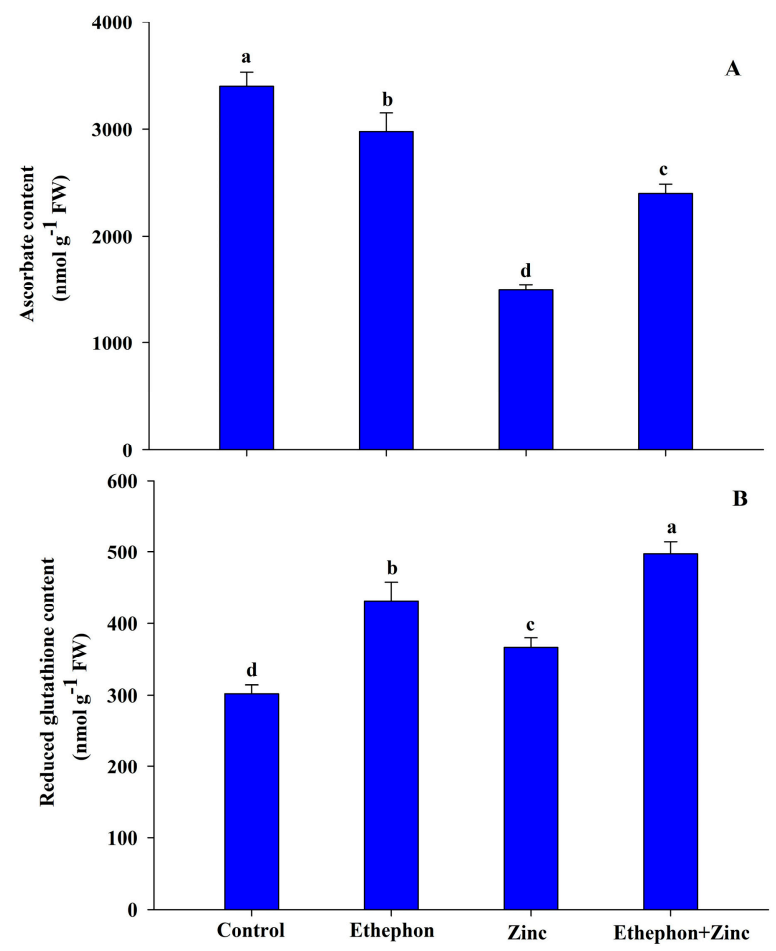

Figure 2. (A) Ascorbate content and (B) reduced glutathione content in the leaf of mustard (Brassica juncea L.) of Varuna cultivar at 30 DAS. Plants were grown with/without $\mathrm{Zn}$ stress and treated with $200 \mu \mathrm{L} \mathrm{L}^{-1}$ ethephon at $20 \mathrm{DAS}$. Data are presented as treatment mean $\pm \mathrm{SE}(n=3)$. Data followed by same letter are not significantly different by LSD test at $p<0.05$.
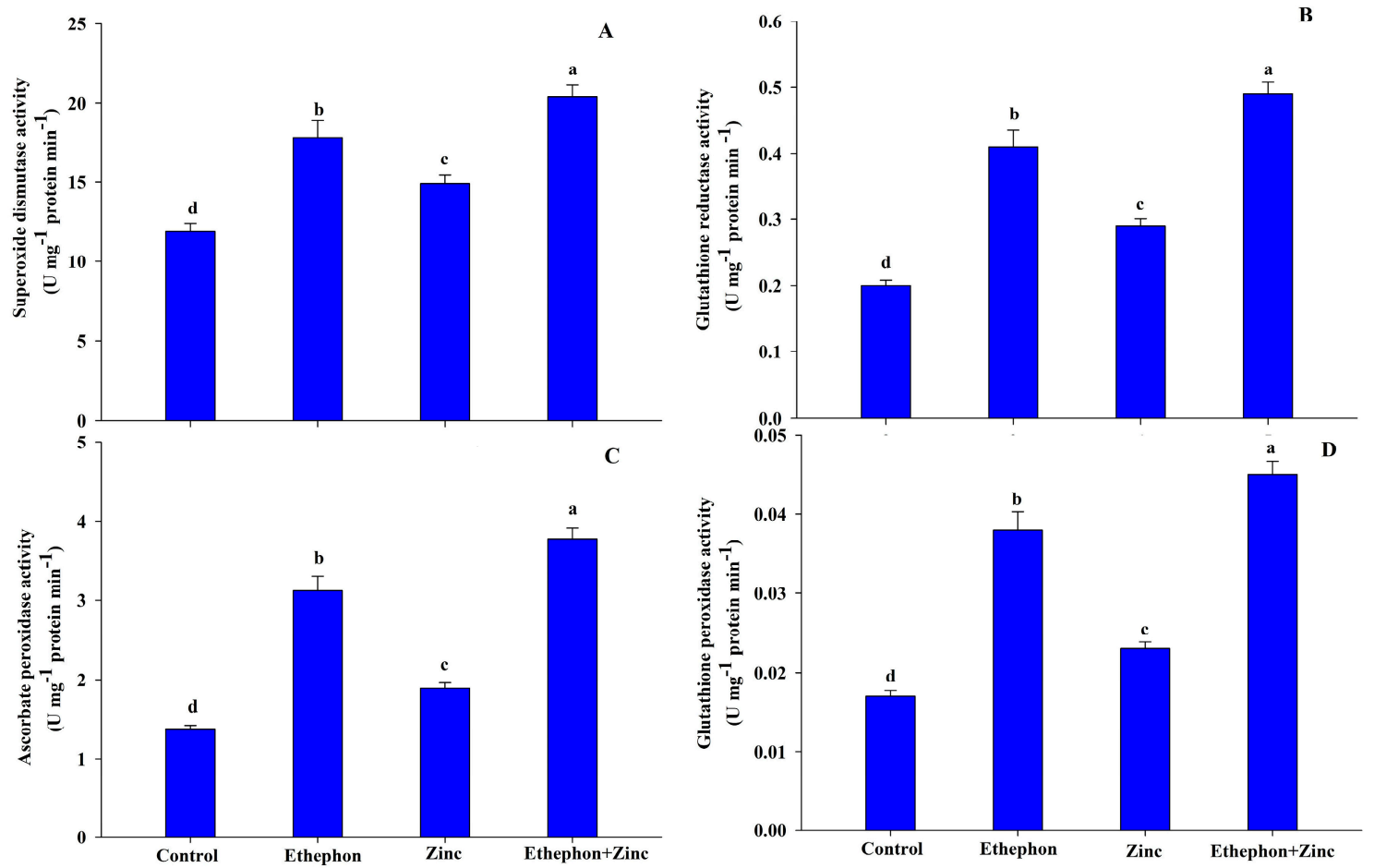

Figure 3. (A) Superoxide dismutase activity; (B) glutathione reductase activity; (C) ascorbate peroxidase activity; (D) and glutathione peroxidase activity in the leaf of mustard (Brassica juncea L.) of Varuna cultivar at 30 DAS. Plants were grown with/without Zn stress and treated with $200 \mu \mathrm{L} \mathrm{L}^{-1}$ ethephon at 20 DAS. Data are presented as treatment mean \pm SE $(n=3)$. Data followed by same letter are not significantly different by LSD test at $p<0.05$. 
Zinc treatments also increased the activity of MDHAR, DHAR, and GST by $45 \%, 26 \%$, and $67 \%$, respectively, as compared to the control plants. Ethephon application to plants grown without $\mathrm{Zn}$ resulted in increased activity of MDHAR by $97 \%$, DHAR by $53 \%$, and GST by $219 \%$, in comparison to control plants; in presence of $\mathrm{Zn}$, ethephon application resulted in $170 \%, 76 \%$, and $261 \%$ higher activity of MDHAR, DHAR, and GST, respectively, in comparison to the control plants (Figure 4).

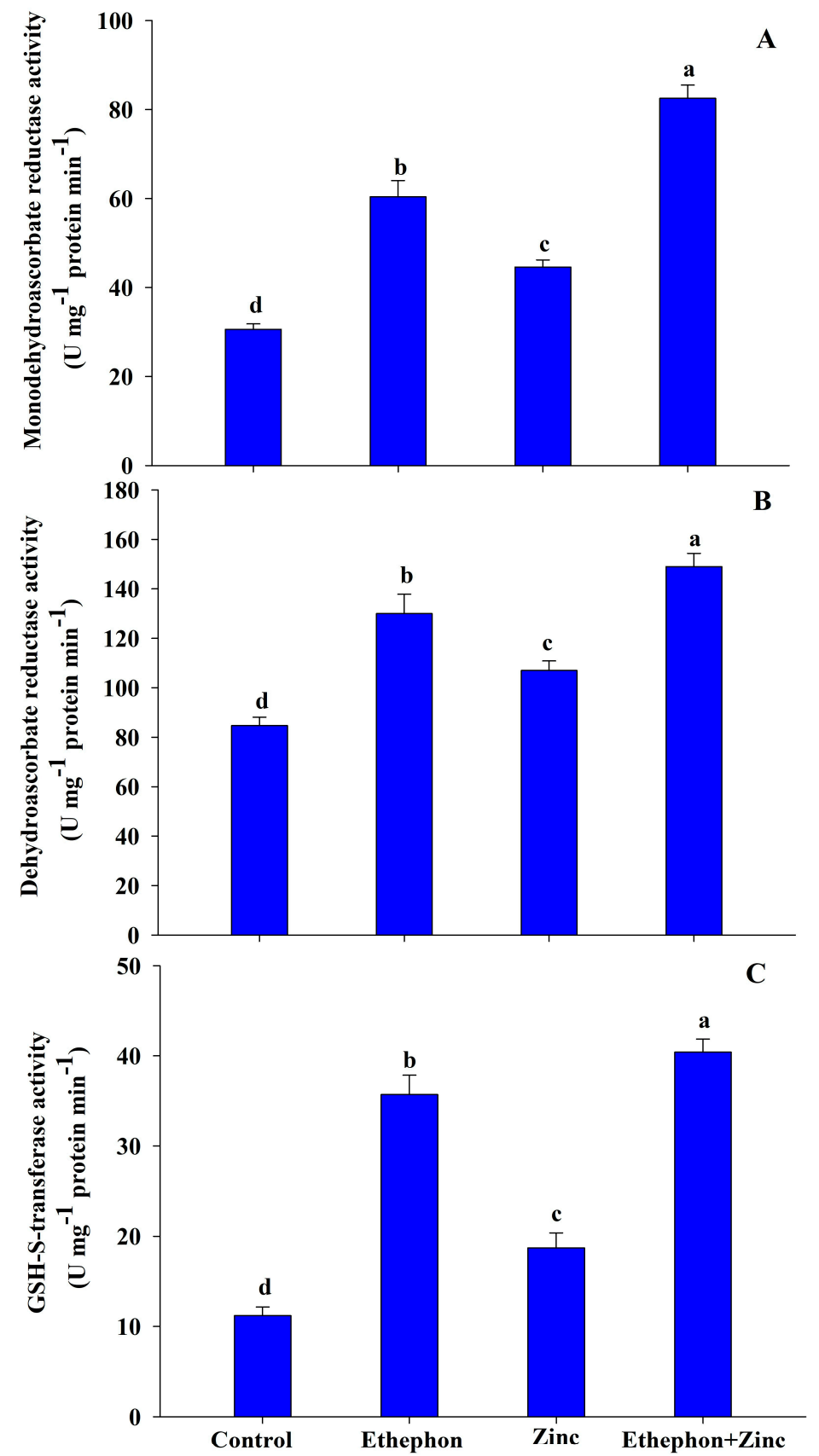

Figure 4. (A) Monodehydroascorbate activity; (B) dehydroascorbate activity; and (C) GSH-S-transferase activity in the leaf of mustard (Brassica juncea L.) of Varuna cultivar at 30 DAS. Plants were grown with/without $\mathrm{Zn}$ stress and treated with $200 \mu \mathrm{L} \mathrm{L}^{-1}$ ethephon at $20 \mathrm{DAS}$. Data are presented as treatment mean \pm SE $(n=3)$. Data followed by same letter are not significantly different by LSD test at $p<0.05$.

\subsection{Ethephon Application Enhances Glyoxalase System}

Gly I was increased with Zn stress by $73 \%$ over the control plants. Application of ethephon to Zn-treated plant significantly enhanced the activity of Gly I by $94 \%$ compared to the control plants 
(Figure 5). The increase in Gly II with Zn stress was $110 \%$ in comparison to the control plants. However, application of ethephon to Zn-treated plants enhanced the activity of Gly II by $160 \%$ as compared to the control plants (Figure 5).

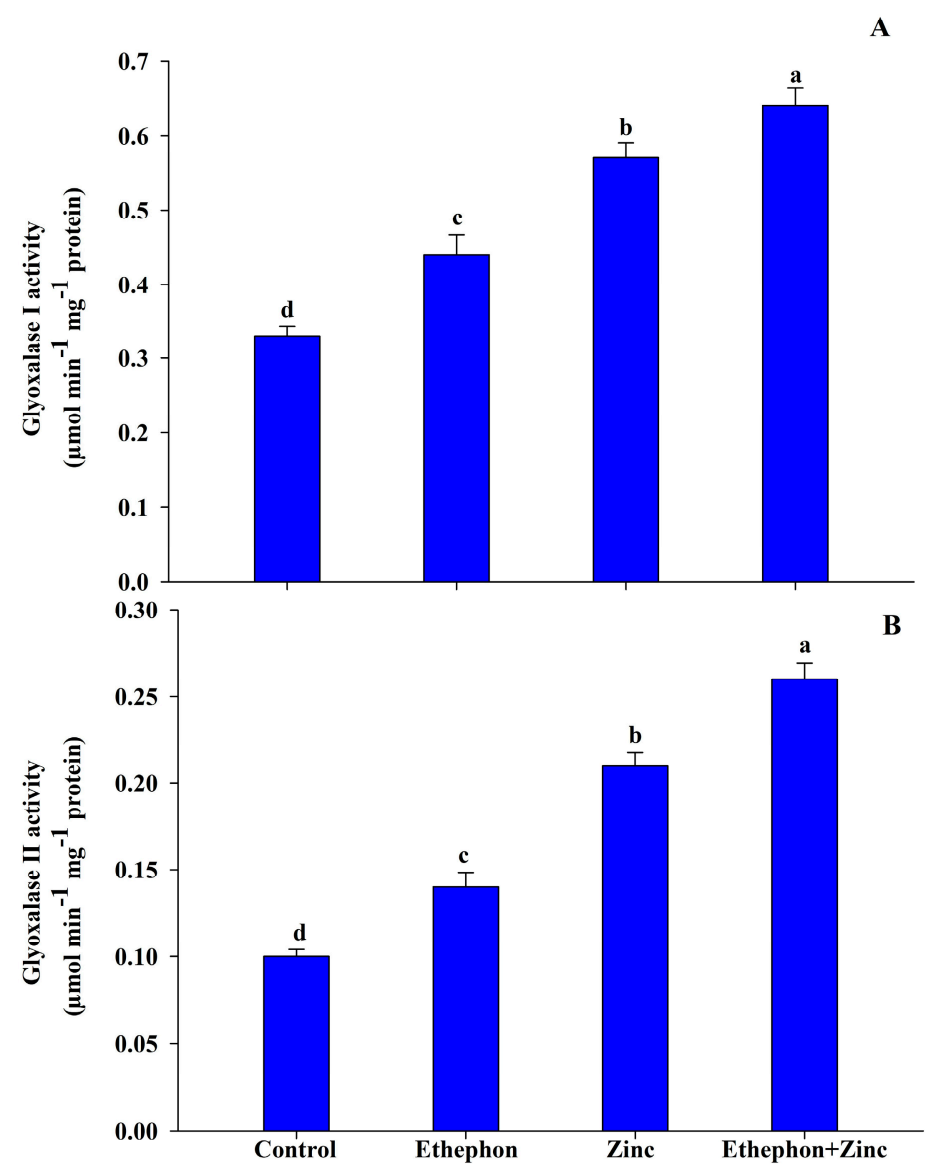

Figure 5. (A) Glyoxalase I activity and (B) glyoxalase II activity in the leaf of mustard (Brassica juncea L.) of Varuna cultivar at 30 DAS. Plants were grown with/without Zn stress and treated with $200 \mu \mathrm{L} \mathrm{L}^{-1}$ ethephon at 20 DAS. Data are presented as treatment mean \pm SE $(n=3)$. Data followed by same letter are not significantly different by LSD test at $p<0.05$.

\subsection{Ethephon Increases Proline Metabolism under Zn Stress}

In order to assess the role of proline metabolism in Zn stress tolerance, assessment of proline accumulation and activity of proline metabolizing enzymes (GK and PROX) was done. Activity of GK increased in Zn-stressed plants and also with ethephon plus $\mathrm{Zn}$ stress treatments. Application of ethephon increased GK activity by $170 \%$ in $\mathrm{Zn}$-stressed plants compared to the control. On the other hand, activity of PROX was reduced under no-stress and Zn-stressed plants with ethephon treatment (Figure 6).

Proline accumulation increased upon ethephon application, as well as with the $\mathrm{Zn}$ treatments. Zinc stress induced proline biosynthesis and increased proline content by $44 \%$ in comparison to the control plants. Proline accumulation under $\mathrm{Zn}$ stress was further increased with ethephon application. Maximum proline accumulation resulted from ethephon application under $\mathrm{Zn}$ stress compared with the control (Figure 6). 

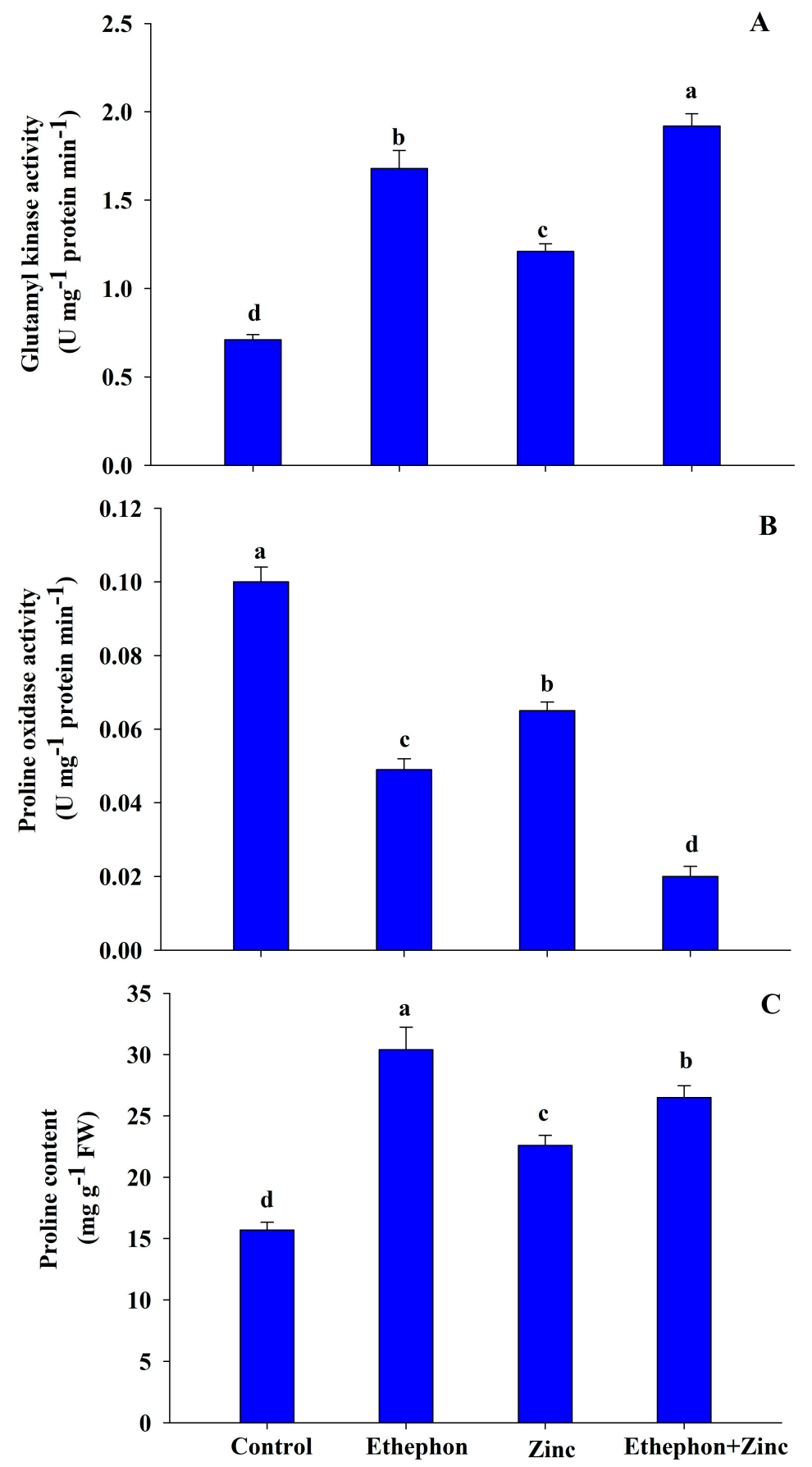

Figure 6. (A) Activity of glutamyl kinase; (B) proline oxidase; and (C) proline content in the leaf of mustard (Brassica juncea L.) of Varuna cultivar at 30 DAS. Plants were grown with/without Zn stress and treated with $200 \mu \mathrm{L} \mathrm{L}^{-1}$ ethephon at 20 DAS. Data are presented as treatment mean $\pm \mathrm{SE}(n=3)$. Data followed by same letter are not significantly different by LSD test at $p<0.05$.

\subsection{Ethephon Supplementation Maintained Nutrient Contents under Zn Stress}

Treatment of ethephon alone significantly increased the content of nutrients but $\mathrm{Zn}$ stress decreased $\mathrm{N}, \mathrm{P}, \mathrm{K}$, and $\mathrm{S}$ content in comparison to the control plants. Zn treatment decreased $\mathrm{N}$ by $29 \%, \mathrm{P}$ by $23 \%$, $\mathrm{K}$ by $31 \%$, and $\mathrm{S}$ by $34 \%$, as compared to control. However, application of ethephon on Zn-grown plants completely alleviated the $\mathrm{Zn}$ effects and increased the nutrient contents significantly in comparison to stressed plants (Figure 7). 

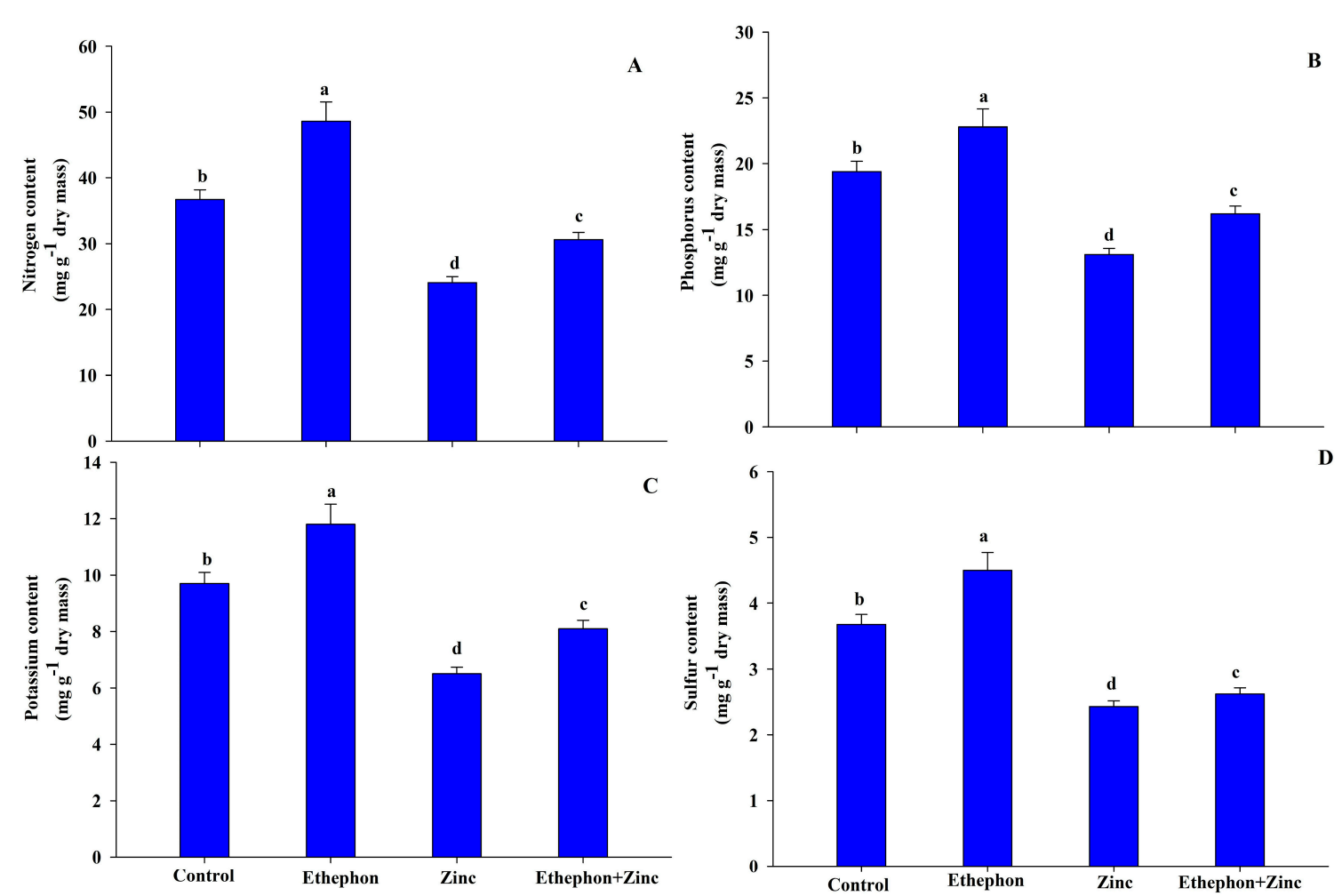

Figure 7. (A) Nitrogen content; (B) phosphorous content; (C) potassium content; and (D) sulfur content in the leaf of mustard (Brassica juncea L.) of Varuna cultivar at 30 DAS. Plants were grown with/without $\mathrm{Zn}$ stress and treated with $200 \mu \mathrm{L} \mathrm{L}^{-1}$ ethephon at 20 DAS. Data are presented as treatment mean $\pm \mathrm{SE}$ $(n=3)$. Data followed by same letter are not significantly different by LSD test at $p<0.05$.

\section{Discussion}

Zinc stress inhibited photosynthesis and plant growth in mustard plants. However, ethephon supplementation not only stimulated photosynthesis and growth under non-stress conditions but also under $\mathrm{Zn}$ stress. Plants show concentration-dependent requirement of $\mathrm{Zn}$ for optimal plant metabolism; however, excess $\mathrm{Zn}$ availability inhibits plant growth and development [24]. It has been reported that HMs induce lipid peroxidation in photosynthetic membranes, distort chloroplast ultrastructure, degrade photosynthetic pigments, inhibit PSII activity and the electron transport chain, and decrease both carboxylation efficiency of Rubisco and net photosynthesis [50,51]. Additionally, plants' fitness to the environment is estimated through chlorophyll fluorescence observations [52]. In the present study, the reduction in photochemical efficiency under Zn stress (Table 1) indicated the interruption in photochemical reactions that blocked electron transport system and the performance of PSII resultantly increased NPQ under Zn stress (Table 1). The results of previous study of Sirhindi et al. [53] have also reported that NPQ increases under Ni stress that was due to repressed photochemistry; this was considered as the mechanism to balance the excess absorbed light energy preventing photo inhibition.

It has been reported that ethylene potentially plays a crucial role in the adaptation of plants to HM stress [54]. Ethephon is used commercially to produce ethylene in crop plants and the ethylene released from ethephon affects several cellular, developmental, photosynthetic, and stress response processes [55]. The present study showed that exogenous ethephon supply decreased the toxic effects of $\mathrm{Zn}$ on photosynthetic machinery (Table 1) and enhanced the activity of PSII and gas exchange parameters. Our results are consistent with the finding of Asgher et al. [56], who reported that ethephon supplementation induced photosynthesis under $\mathrm{Cr}$ stress.

In the present study, Zn-stressed plants were at substantially increased oxidative stress and MG levels exhibiting increased LOX activity. These observations in mustard plants are in agreement with the finding of Molassiotis et al. [57], who found increased LOX activity which was the result of 
increased production of ROS due to higher oxidative stress in Malus domestica shoot tips under boron stress. Our results showed a possible regulatory role of exogenously applied ethylene as ethephon on ROS and MG metabolism in Zn stress tolerance in mustard plants. Indeed, ethylene acts as a vital signaling molecule for reduction of ROS $[19,58]$. Earlier, it has been shown that coordination and regulation of the antioxidant systems and glyoxalase systems are indispensable to attain significant tolerance against oxidative stress $[59,60]$. We have found that the activity of antioxidant enzymes and glyoxalase system simultaneously work to reduce excess ROS load and MG detoxification.

Antioxidant enzyme systems are part of an imperative defense system of plants against ROS caused by HMs [61]. Application of ethephon substantially induced the activity of SOD, APX, GR, GST, GPX, MDHAR, and DHAR in plants under Zn stress. Further, ethylene application enhanced the activities of Gly I and Gly II, particularly in response to Zn stress. Recently, Hassanuzzaman et al. [62] showed that the activities of Gly I and Gly II in Oryza sativa increased under Ni stress and Si application. Studies have shown that ethephon treatment influenced the activity of antioxidant enzymes and photosynthetic attributes, but the information on the response of plants to ethephon under $\mathrm{Zn}$ stress is scanty. In the present study, the effort was made to understand the role of ethylene in regulation of three major defense mechanisms (antioxidant system, glyoxalase system, and proline metabolism) along with nutrient homeostasis under high level of $\mathrm{Zn}$ in mustard plants. Ethylene significantly induced the defense mechanisms by up-regulating the key enzymes in the antioxidant system (SOD, APX, GR, GPX, GST), glyoxalase system (Gly I and Gly II) and proline metabolism (GK and PROX), which resulted in protection of growth and development of plants through maintaining water relations and increasing PS II activity and dry mass production.

In addition to the antioxidant and glyoxalase defense system, we also examined proline as a defense mechanism under $\mathrm{Zn}$ stress and to know how it was modulated with ethylene. Plants under $\mathrm{Zn}$ stress accumulated proline. These results are supported with the previous findings of Sirhindi et al. [53], who have shown that proline content increases in Glycine max under Ni toxicity. Alia et al. [63] showed that proline was involved in reducing the photodamage in the thylakoid membranes by scavenging ROS (singlet oxygen and superoxide radical anion). In the present study, ethylene-induced accumulation of proline helped in increasing osmotic potential, and thereby water potential, and protected PSII activity and photosynthesis by reducing ROS effects under Zn stress. The activity of chlorophyll fluorescence was reduced in Zn-stressed plants receiving ethylene that showed improved photosynthesis. Earlier, it has been shown that ethephon application increased the gas exchange parameters and PSII activity in mustard under HM stress [56,58]. Proline biosynthesis has been attributed in the alleviation of cytoplasmic acidosis and may maintain $\mathrm{NADP}^{+} / \mathrm{NADPH}$ ratio at values compatible with plant metabolism. Rapid production of proline under stress also provides recovery from stress-induced damages to mitochondrial oxidative phosphorylation and the generation of ATP [64]. However, there has been much disagreement regarding the mechanisms by which proline reduces HM-induced oxidative stress, regulates cellular functions such as osmotic adjustment, and enhances the plant's water status [14]. In the present research, efforts were made to study the role of proline and its metabolizing enzymes in facilitating $\mathrm{Zn}$ detoxification and ameliorating stress in mustard plants. The increased proline accumulation after ethephon application resulted from induced GK activity and inhibited PROX activity. It has been reported that activities of GK and PROX play important roles in controlling the level of proline and environmental stress in plants $[65,66]$. The regulatory role of ethylene in proline metabolism and its enzymes to improve photosynthetic traits under $\mathrm{Cd}$ and heat stress has been shown [21,22].

HMs impact negatively on the environment and crop nutrition [67]. They disturb the uptake of essential nutrients such as $\mathrm{N}, \mathrm{P}, \mathrm{K}$, and $\mathrm{S}$ which are required for normal growth of plants $[68,69]$. In the present study, we also focused on modulation of essential nutrients (N, P, K, and S) in mustard plants through application of ethephon under $\mathrm{Zn}$ stress. Ethylene has been associated with the regulation of physiological responses to nutrient homeostasis and stress tolerance responses. Efficient working of nutrient transporters and enzymes involved in nutrient assimilation enhanced nutrient uptake and this 
has a direct influence on the tolerance mechanisms including antioxidant system, glyoxalase system, and proline metabolism of plants under stress condition [70].

\section{Conclusions and Future Prospects}

Conclusively, it may be said that Zn stress adversely impacted photosynthesis and growth of plants by inhibiting metabolic pathways. Ethylene supplementation inhibited ROS production through induced defense mechanisms of antioxidant activity, proline metabolism, glyoxalase system and nutrient homoeostasis. It protected photosynthetic machinery and promoted photosynthesis and growth under $\mathrm{Zn}$ stress. Thus, the use of ethylene (as ethephon) may bear a prominent role in alleviation of $\mathrm{Zn}$ stress in mustard plants by modulating the defense mechanisms.

Author Contributions: N.A.K. and M.I.R.K. conceptualized the study and wrote the manuscript; M.I.R.K. and B.J. conducted the experiments; M.I.R.K., B.J., M.F.A. and M.T.R. analyzed the data. All authors have read the manuscript and approved without any conflicts.

Funding: This research received no external funding.

Conflicts of Interest: The authors declare that they have no conflict of interest.

\section{References}

1. Rizwan, M.; Ali, S.; Rehman, M.Z.; Maqbool, A. A critical review on the effects of zinc at toxic levels of cadmium in plants. Environ. Sci. Pollut. Res. 2019, 26, 6279-6289. [CrossRef]

2. Salla, V.; Hardaway, C.J.; Sneddon, J. Preliminary investigation of Spartina alterniflora for phytoextraction of selected heavy metals in soils from Southwest Louisiana. Microchem. J. 2011, 97, 207-212. [CrossRef]

3. Shahid, M.; Khalid, S.; Abbas, G.; Shahid, N.; Nadeem, M.; Sabir, M. Heavy Metal Stress and Crop Productivity. In Crop Production and Global Environmental Issues; Hakeem, K.R., Ed.; Springer: Cham, Switzerland, 2015; pp. 1-25.

4. Marschner, H. Mineral Nutrition of Higher Plants, 2nd ed.; Academic Press: New York, NY, USA, 1995.

5. Broadley, M.R.; White, P.J.; Hammond, J.P.; Zelko, I.; Lux, A. Zinc in plants. New Phytol. 2007, 173, 677-702. [CrossRef] [PubMed]

6. Feigl, G.; Lehotai, N.; Molnár, Á.; Ördög, A.; Rodríguez-Ruiz, M.; Palma, J.M.; Corpas, F.J.; Erdei, L.; Kolbert, Z. Zinc induces distinct changes in the metabolism of reactive oxygen and nitrogen species (ROS and RNS) in the roots of two Brassica species with different sensitivity to zinc stress. Ann. Bot. 2015, 116, 613-625. [CrossRef] [PubMed]

7. He, J.; Wang, Y.; Ding, H.; Ge, C. Epibrassinolide confers zinc stress tolerance by regulating antioxidant enzyme responses, osmolytes, and hormonal balance in Solanum melongena seedlings. Braz. J. Bot. 2016, 39, 295-303. [CrossRef]

8. Cakmak, I. Possible Roles of Zinc in Protecting Plant Cells from Damage by Reactive Oxygen Species. New Phytol. 2000, 146, 185-205. [CrossRef]

9. Zhao, H.; Zheng, W. Effects of zinc stress on growth and antioxidant enzyme responses of Kandelia obovata seedlings. Toxicol. Environ. Chem. 2015, 97, 1190-1201.

10. Anjum, N.A.; Singh, H.P.; Khan, M.I.R.; Masood, A.; Per, T.S.; Negi, A.; Ahmad, I. Too much is bad-an appraisal of phytotoxicity of elevated plant-beneficial heavy metal ions. Environ. Sci. Pollut. Res. 2015, 22, 3361-3382. [CrossRef]

11. Anwaar, S.A.; Ali, S.; Ali, S.; Ishaque, W.; Farid, M.; Farooq, M.A.; Najeeb, U.; Abbas, F.; Sharif, M. Silicon (Si) alleviates cotton (Gossypium hirsutum L.) from zinc $(\mathrm{Zn})$ toxicity stress by limiting $\mathrm{Zn}$ uptake and oxidative damage. Environ. Sci. Pollut. Res. 2015, 22, 3441-3450. [CrossRef]

12. Khan, M.I.R.; Khan, N. Reactive Oxygen Species and Antioxidant System in Plants: Role and Regulation under Abiotic Stress; Springer: Berlin/Heidelberg, Germany, 2017.

13. Noctor, G.; Foyer, C.H. Ascorbate and glutathione: Keeping active oxygen under control. Annu. Rev. Plant Physiol. 1998, 49, 249-279. [CrossRef]

14. Nahar, K.; Hasanuzzaman, M.; Suzuki, T.; Fujita, M. Polyamines-induced aluminum tolerance in mung bean: A study on antioxidant defense and methylglyoxal detoxification systems. Ecotoxicology 2017, 26, 58-73. [CrossRef] [PubMed] 
15. Foyer, C.H.; Noctor, G. Ascorbate and glutathione: The heart of the redox hub. Plant Physiol. 2011, 155, 2-18. [CrossRef] [PubMed]

16. Kaur, C.; Sharma, S.; Singla-Pareek, S.L.; Sopory, S.K. Methylglyoxal detoxification in plants: Role of glyoxalase pathway. Indian J. Plant Physiol. 2016, 21, 377-390. [CrossRef]

17. Per, T.S.; Khan, N.A.; Reddy, P.S.; Masood, A.; Hasanuzzaman, M.; Khan, M.I.R.; Anjum, N.A. Approaches in modulating proline metabolism in plants for salt and drought stress tolerance: Phytohormones, mineral nutrients and transgenics. Plant Physiol. Biochem. 2017, 115, 126-140. [CrossRef] [PubMed]

18. Misra, N.; Saxena, P. Effect of salicylic acid on proline metabolism in lentil grown under salinity stress. Plant Sci. 2009, 177, 181-189. [CrossRef]

19. Khan, N.A.; Khan, M.I.R.; Ferrante, A.; Poor, P. Editorial: Ethylene: A key regulatory molecule in plants. Front. Plant Sci. 2017, 8, 1782. [CrossRef]

20. Pahwa, K.; Ghai, N.; Kaur, J.; Singh, I.; Singh, S.; Dhingra, M. Influence of ethylene and cobalt chloride on photosynthetic parameters and pedicel anatomy of pigeon pea (Cajanus cajan L.) genotypes. J. Environ. Biol. 2017, 38, 367-374. [CrossRef]

21. Iqbal, N.; Khan, N.A.; Nazar, R.; Silva, J.A. Ethylene-stimulated photosynthesis results from increased nitrogen and sulfur assimilation in mustard types that differ in photosynthetic capacity. Environ. Exp. Bot. 2012, 78, 84-90. [CrossRef]

22. Khan, M.I.R.; Iqbal, N.; Masood, A.; Per, T.S.; Khan, N.A. Salicylic acid alleviates adverse effects of heat stress on photosynthesis through changes in proline production and ethylene formation. Plant Signal. Behav. 2013, 8, e26374. [CrossRef]

23. Khan, M.I.R.; Nazir, F.; Asgher, M.; Per, T.S.; Khan, N.A. Selenium and sulfur influence ethylene formation and alleviate cadmium-induced oxidative stress by improving proline and glutathione production in wheat. J. Plant Physiol. 2015, 173, 9-18. [CrossRef]

24. Khan, M.I.R.; Khan, N.A. Ethylene reverses photosynthetic inhibition by nickel and zinc in mustard through changes in PS II activity, photosynthetic nitrogen use efficiency, and antioxidant metabolism. Protoplasma 2014, 251, 1007-1019. [CrossRef] [PubMed]

25. Usuda, H. The activation state of ribulose 1,5-bisphosphate carboxylase in maize leaves in dark and light. Plant Cell Physiol. 1985, 26, 1455-1463.

26. Krall, J.P.; Edwards, G.E. Relationship between photosystem II activity and $\mathrm{CO}_{2}$ fixation in leaves. Physiol. Plant. 1992, 86, 180-187. [CrossRef]

27. Dhindsa, R.H.; Plumb-Dhindsa, P.; Thorpe, T.A. Leaf senescence correlated with increased level of membrane permeability, lipid peroxidation and decreased level of SOD and CAT. J. Exp. Bot. 1981, 32, 93-101. [CrossRef]

28. Wild, R.; Ooi, L.; Srikanth, V.; Münch, G. A quick, convenient and economical method for the reliable determination of methylglyoxal in millimolar concentrations: The N-acetyl-L-cysteine assay. Anal. Bioanal. Chem. 2012, 403, 2577-2581. [CrossRef]

29. Doderer, A.; Kokkelink, I.; van der Veen, S.; Valk, B.; Schram, A.; Douma, A. Purification and characterization of two Lipoxygenase isoenzymes from germinating barley. Biochim. Biophys. Acta 1992, 112, 97-104. [CrossRef]

30. Law, M.E.; Charles, S.A.; Halliwell, B. Glutathione and ascorbic acid in spinach (Spinacia oleracea) chloroplasts: The effect of hydrogen peroxide and of paraquat. Biochem. J. 1983, 210, 899-903. [CrossRef]

31. Anjum, N.A.; Umar, S.; Iqbal, M.; Khan, N.A. Cadmium causes oxidative stress in mung bean by affecting the antioxidant enzyme system and ascorbate-glutathione cycle metabolism. Russ. J. Plant Physiol. 2011, 58, 92-99. [CrossRef]

32. Griffith, O.W. Determination of GSH disulphide using GSH reductase and 2-vinylpyridine. Anal. Biochem. 1980, 106, 207-211. [CrossRef]

33. Masood, A.; Khan, M.I.R.; Fatma, M.; Asgher, M.; Per, T.S.; Khan, N.A. Involvement of ethylene in gibberellic acid-induced sulfur assimilation, photosynthetic responses, and alleviation of cadmium stress in mustard. Plant Physiol. Biochem. 2016, 104, 1-10. [CrossRef]

34. Bradford, M.M. A rapid and sensitive method for the Quantitation of micro-gram quantities of proteins utilising the principle of protein-dye binding. Anal. Biochem. 1976, 72, 248-254. [CrossRef]

35. Beyer, W.F.; Fridovich, I. Assaying for superoxide dismutase activity: Some large consequences of minor changes in conditions. Anal. Biochem. 1987, 161, 559-566. [CrossRef] 
36. Giannopolitis, C.N.; Ries, S.K. Superoxide dismutase. I. Occurrence in higher plants. Plant Physiol. 1977, 59, 309-314. [CrossRef] [PubMed]

37. Nakano, Y.; Asada, K. Hydrogen peroxide is scavenged by ascorbate specific peroxidase in spinach chloroplasts. Plant Cell Physiol. 1981, 22, 867-880.

38. Foyer, C.H.; Halliwell, B. The presence of glutathione and glutathione reductase in chloroplasts: A proposed role in ascorbic acid metabolism. Planta 1976, 133, 21-25. [CrossRef]

39. Hasanuzzaman, M.; Hossain, M.A.; Fujita, M. Exogenous selenium pretreatment protects rapeseed seedlings from cadmium-induced oxidative stress by up regulating antioxidant defense and methylglyoxal detoxification systems. Biol. Trace Elem. Res. 2012, 149, 248-261. [CrossRef]

40. Booth, J.; Boyland, E.; Sims, P. An enzyme from rat liver catalyzing conjugation. Biochem. J. 1961, 79, $516-524$.

41. Hossain, M.A.; Hossain, M.Z.; Fujita, M. Stress induced changes of methylglyoxal level and glyoxalase I activity in pumpkin seedlings and cDNA cloning of glyoxalase I gene. Aust. J. Crop Sci. 2009, 3, 53-64.

42. Hossain, M.A.; Nakano, Y.; Asada, K. Monodehydroascorbate reductase in spinach chloroplasts and its participation in the regeneration of ascorbate for scavenging hydrogen peroxide. Plant Cell Physiol. 1984, 25, 385-395.

43. Hasanuzzaman, M.; Nahar, K.; Anee, T.I.; Khan, M.I.R.; Fujita, M. Silicon-mediated regulation of antioxidant defense and glyoxalase systems confers drought stress tolerance in Brassica napus L. S. Afr. J. Bot. 2018, 115, 50-57. [CrossRef]

44. Principato, G.B.; Rosi, G.; Talesa, V.; Giovanni, E.; Uotila, L. Purification and characterization of two forms of glyoxalase II from the liver and brain of wistar rats. Biochim. Biophys. Acta 1987, 911, 349-355. [CrossRef]

45. Lindner, R.C. Rapid analytical methods for some of the more common inorganic constituents of plant tissues. Plant Physiol. 1944, 19, 70-89. [CrossRef] [PubMed]

46. Fiske, C.H.; Subba Row, Y. The colorimetric determination of phosphorus. J. Biol. Chem. 1925, 66, $375-400$.

47. Bates, L.E.; Waldren, R.P.; Teare, I.D. Rapid determination of free proline for water stress studies. Plant Soil 1973, 39, 205-207. [CrossRef]

48. Hayzer, D.J.; Leisinger, T.H. The gene-enzyme relationships of proline biosynthesis in Escherichia coli. J. Gen. Microbial. 1980, 118, 287-293. [CrossRef]

49. Huang, A.H.C.; Cavalieri, A.J. Proline oxidase and water stress induced proline accumulation in spinach leaves. Plant Physiol. 1979, 63, 531-535. [CrossRef]

50. Mishra, S.; Dubey, R. Heavy Metal Toxicity induced Alterations in Photosynthetic Metabolism in Plants. In Handbook of Photosynthesis; Pessarakli, M., Ed.; CRC Press: Boca Raton, FL, USA, 2005; pp. 827-844.

51. Chen, Y.; Wu, N.; Zhang, Z.W.; Yuan, M.; Yuan, S. Perspective of Monitoring Heavy Metals by Moss Visible Chlorophyll Fluorescence Parameters. Front. Plant Sci. 2019, 10, 35. [CrossRef]

52. Bączek-Kwinta, R.; Antonkiewicz, J.; Łopata-Stasiak, A.; Kępka, W. Smoke compounds aggravate stress inflicted on Brassica seedlings by unfavorable soil conditions. Photosynthetica 2019, 57, 1-8. [CrossRef]

53. Sirhindi, G.; Mir, M.A.; Abd-Allah, E.F.; Ahmad, P.; Gucel, S. Jasmonic acid modulates the physio-biochemical attributes, antioxidant enzyme activity, and gene expression in Glycine max under nickel toxicity. Front. Plant Sci. 2016, 7, 591. [CrossRef]

54. Thao, N.P.; Khan, M.I.R.; Thu, N.B.A.; Hoang, X.L.T.; Asgher, M.; Khan, N.A.; Tran, L.S.P. Role of ethylene and its cross talk with other signaling molecules in plant responses to heavy metal stress. Plant Physiol. 2015, 169, 73-84. [CrossRef]

55. Khan, N.A.; Mir, M.R.; Nazar, R.; Singh, S. The application of ethephon (an ethylene releaser) increases growth, photosynthesis and nitrogen accumulation in mustard (Brassica juncea L.) under high nitrogen levels. Plant Biol. 2008, 10, 534-538. [CrossRef] [PubMed]

56. Asgher, M.; Per, T.S.; Verma, S.; Pandith, S.A.; Masood, A.; Khan, N.A. Ethylene supplementation increases PSII Efficiency and alleviates chromium-inhibited photosynthesis through increased nitrogen and sulfur assimilation in mustard. J. Plant Growth Regul. 2018, 37, 1300-1317. [CrossRef]

57. Molassiotis, A.; Sotiropoulos, T.; Tanou, G.; Diamantidis, G.; Therios, I. Boron induced oxidative damage and antioxidant and nucleolytic responses in shoot tips culture of the apple rootstock EM9 (Malus domestica Borkh). Environ. Exp. Bot. 2006, 56, 54-62. [CrossRef]

58. Khan, N.A.; Asgher, M.; Per, T.S.; Masood, A.; Fatma, M.; Khan, M.I.R. Ethylene potentiates sulfur-mediated reversal of cadmium inhibited photosynthetic responses in mustard. Front. Plant Sci. 2016, 7, 1628. [CrossRef] [PubMed] 
59. Álvarez Viveros, M.F.; Inostroza-Blancheteau, C.; Timmermann, T.; González, M.; Arce-Johnson, P. Overexpression of Gly I and Gly II genes in transgenic tomato (Solanum ycopersicum Mill.) plants confers salt tolerance by decreasing oxidative stress. Mol. Biol. Rep. 2013, 40, 3281-3290. [CrossRef]

60. Mostofa, M.G.; Hossain, M.A.; Fujita, M. Trehalose pretreatment induces salt tolerance in rice (Oryza sativa L.) seedlings: Oxidative damage and co-induction of antioxidant defense and glyoxalase systems. Protoplasma 2015, 252, 461-475. [CrossRef] [PubMed]

61. Halliwell, B.; Gutteridge, J. Oxygen toxicity, oxygen radicals, transition metals and disease. Biochem. J. 1984, 219, 1-14. [CrossRef]

62. Hasanuzzaman, M.; Alam, M.M.; Nahar, K.; Mohsin, S.M.; Bhuyan, M.B.; Parvin, K.; Hawrylak-Nowak, B.; Fujita, M. Silicon-induced antioxidant defense and methylglyoxal detoxification works coordinately in alleviating nickel toxicity in Oryza sativa L. Ecotoxicology 2019, 28, 261-276. [CrossRef]

63. Alia; Saradhi, P.P.; Mohanty, P. Involvement of proline in protecting thylakoid membranes against free radical-induced photodamage. J. Photochem. Photobiol. 1997, 38, 253-257. [CrossRef]

64. Hare, P.D.; Cress, W.A. Metabolism implications of stress-induced proline accumulation in plants. Plant Growth Regul. 1997, 21, 79-102. [CrossRef]

65. Szabados, L.; Savoure, A. Proline: Multifunctional amino acid. Trends Plant Sci. 2010, 15, 89-97. [CrossRef] [PubMed]

66. Iqbal, N.; Umar, S.; Khan, N.A. Nitrogen availability regulates proline and ethylene production and alleviates salinity stress in mustard (Brassica juncea). J. Plant Physiol. 2015, 178, 84-91. [CrossRef] [PubMed]

67. Antonkiewicz, J.; Czesława, J.; Małgorzata, K.; Renata, S. Nickel bioaccumulation by the chosen plant species. Acta Physiol. Plant. 2016, 38, 40. [CrossRef]

68. Munns, R.; Tester, M. Mechanisms of salinity tolerance. Annu. Rev. Plant Biol. 2008, 59, 651-681. [CrossRef] [PubMed]

69. Hussain, S.; Khan, A.M.; Rengel, Z. Zinc-biofortified wheat accumulates more cadmium in grains than standard wheat when grown on cadmium-contaminated soil regardless of soil and foliar zinc application. Sci. Total Environ. 2019, 654, 402-408. [CrossRef] [PubMed]

70. Ahanger, M.A.; Agarwal, R.M. Salinity stress induced alterations in antioxidant metabolism and nitrogen assimilation in wheat (Triticum aestivum $\mathrm{L}$ ) as influenced by potassium supplementation. Plant Physiol. Biochem. 2017, 115, 449-460. [CrossRef] 